University of Nebraska - Lincoln

DigitalCommons@University of Nebraska - Lincoln

Faculty Papers and Publications in Animal

Science

Animal Science Department

1987

\title{
Relationships Between Rate of Growth, Catheptic Enzymes and Meat Palatability in Young Bulls
}

Chris R. Calkins

University of Nebraska-Lincoln, ccalkins1@unl.edu

S. C. Seideman

Bryan Foods, West Point, MS

J. D. Crouse

USDA-ARS

Follow this and additional works at: https://digitalcommons.unl.edu/animalscifacpub

Part of the Animal Sciences Commons

Calkins, Chris R.; Seideman, S. C.; and Crouse, J. D., "Relationships Between Rate of Growth, Catheptic Enzymes and Meat Palatability in Young Bulls" (1987). Faculty Papers and Publications in Animal Science. 566.

https://digitalcommons.unl.edu/animalscifacpub/566

This Article is brought to you for free and open access by the Animal Science Department at DigitalCommons@University of Nebraska - Lincoln. It has been accepted for inclusion in Faculty Papers and Publications in Animal Science by an authorized administrator of DigitalCommons@University of Nebraska - Lincoln. 


\title{
RELATIONSHIPS BETWEEN RATE OF GROWTH, CATHEPTIC ENZYMES AND MEAT PALATABILITY IN YOUNG BULLS ${ }^{1,2}$
}

\author{
C. R. Calkins ${ }^{3}$, S. C. Seideman ${ }^{4}$ and J. D. Crouse $e^{5,6}$ \\ University of Nebraska \\ Lincoln 68583
}

\begin{abstract}
Relationships between rate of growth, endogenous muscle enzymes and meat palatability were investigated in 48 young (13 mo) Angus bulls. After backgrounding for $4 \mathrm{mo}$, bulls were placed on a high-energy diet for $30 \mathrm{~d}$, at which time they were assigned randomly to one of three feeding treatments: 1) high energy (ad libitum-fed), 2) maintenance energy (restriction-fed to maintain body weight) or 3) sub-maintenance energy (restriction-fed to lose $.68 \mathrm{~kg} / \mathrm{d}$ ). Cattle were slaughtered after 30 or $60 \mathrm{~d}$ on trial. Cathepsins $B$ and $H$ and $\beta$-glucuronidase in the longissimus muscle were quantitated at slaughter. Serum hydroxyproline, longissimus muscle collagen, taste-panel ratings and peak load for shear were obtained. Rate of growth did not influence enzyme or palatability traits and, although differences were noted for plasma hydroxyproline, muscle collagen amount and solubility were unchanged. Overall, about one-half of the variation in serum hydroxyproline, muscle collagen, taste-panel ratings and shear-force value could be explained by collective differences in selected enzyme traits. These data indicate that a significant relationship exists between proteolytic activity of longissimus muscle and meat tenderness.

(Key Words: Beef, Growth Rate, Cathepsins, Tenderness.)
\end{abstract}

\section{Introduction}

Aberle et al. (1981) suggested that rate of growth in steers is more important in determining tenderness than time on feed. They attributed the benefits of rapid growth rates to enhanced collagen solubility and hypothesized that variable amounts or activities of endogenous proteolytic enzymes might exist within muscle at the time of slaughter. Similar benefits of rapid growth have been observed by Fishell et al. (1985) and Miller et al. (1983). Hall and Hunt (1982) reported that cattle initially fed high-energy diets and converted to low-energy diets before slaughter had reduced growth

\footnotetext{
${ }^{1}$ Journal series no. 8128, Agr. Res. Div., Univ. of Nebraska.

${ }^{2}$ Mention of trade names or companies does not constitute an implied warranty (or endorsement) by the USDA and does not imply its approval to the exclusion of other products that may also be suitable.

${ }^{3}$ Dept. of Anim. Sci.

${ }^{4}$ Currently with Bryan Foods, West Point, MS 39773.

${ }^{5}$ USDA-ARS, Roman L. Hruska U.S. Meat Anim. Res. Center, P.O. Box 166, Clay Center, NE 68933.

'The authors acknowledge Allen L. Maddy for his assistance with data collection.

Received August 1, 1986.

Accepted January 4, 1987.
}

rates near slaughter and tended to produce less tender meat with less soluble collagen than cattle fed a high-energy diet throughout the finishing period. Collagen turnover is reportedly accelerated during periods of rapid growth (Wu et al., 1981). Thus, it appears that rate of growth influences tenderness of beef, perhaps through endogenous proteolytic enzymes.

An increased growth rate may be characterized by an increase in the rate of tissue deposition, predominantly muscle. It is well known that accretion is the net difference between synthesis and degradation. During accelerated growth, both reactions are enhanced, but synthesis to a greater extent than degradation (Millward et al., 1975; Millward and Waterflow, 1978). Bird et al. (1978) and many others have demonstrated that several cathepsins are capable of degrading the stromal and contractile proteins. If endogenous catheptic enzymes are related to protein turnover in living muscle and to tenderness and collagen characteristics of postmortem muscle, then an increase in the amount of muscle cathepsins during rapid rates of growth would be expected, and enhanced tenderness would result. This study was conducted to determine the relationship between rate of growth and cathepsins and to examine the effect of cathepsins on palatability and collagen characteristics. 


\section{Materials and Methods}

A detailed discussion of the bulls used in this study and the textural measurements of the longissimus muscle has been reported by Crouse et al. (1986). Briefly, 48 Angus bulls were fed a growing diet for 4 mo after weaning and then, at about 13 mo of age, were placed on a finishing diet ( $84 \%$ total digestible nutrients) composed of corn and corn silage. After $30 \mathrm{~d}$ on the finishing diet, bulls were randomly assigned to one of three groups to create differences in rate of gain : 1) high energy (ad libitum-fed), 2) maintenance energy (restriction-fed to maintain body weight) or 3 ) sub-maintenance energy (restriction-fed to lose $.68 \mathrm{~kg} / \mathrm{d}$ ). Bulls were penned by treatment and fed (four per pen) in two replicated pens ( 12 pens total).

After $30 \mathrm{~d}$ on the specific feeding treatments (about 15 mo of age), two bulls per pen were slaughtered. The remaining cattle were slaughtered after an additional $30 \mathrm{~d}$ on feed.

At the time of exsanguination, blood was collected and the serum separated and frozen. Protein and non-protein hydroxyproline were assayed using the separation procedures of Bannister and Burns (1970) and the quantitation procedures of Bergman and Loxley (1963).

For proteolytic enzyme-activity determinations, a longissimus muscle sample was removed from the region of the third lumbar vertebra within $1 \mathrm{~h}$ of exsanguination and placed on ice. Ten grams of finely minced muscle was homogenized in $50 \mathrm{ml}$ of $.02 \mathrm{M} \mathrm{KCl}, .25 \mathrm{M}$ sucrose following the procedures of Moeller et al. (1976). The homogenate was centrifuged at $3,000 \times \mathrm{g}$ for $5 \mathrm{~min}$, resuspended in $30 \mathrm{ml}$ of $.02 \mathrm{M} \mathrm{KCl}$, $.25 \mathrm{M}$ sucrose and resedimented. The pooled supernatant fractions $(30-\mathrm{ml}$ aliquots) were ultracentrifuged at $102,000 \times \mathrm{g}$ for $2 \mathrm{~h}$. The resulting pellet and supernatant fractions were used to assess the amount of bound and unbound proteolytic enzymes, respectively. Total protein extracted in each fraction was determined with biuret reagent.

Amounts of cathepins $B$ and $H$ were quantitated using the procedures of Barrett (1980) and the amount of $\beta$-glucuronidase was determined using the procedures of Moeller et al. (1976). Total activity of each enzyme was calculated as the apparent specific activity multiplied by the protein concentration in the final supernatant or pellet fraction.

Longissimus muscle from the rib was trimmed of epimysial connective tissue and powdered in a blender with liquid nitrogen. Samples (4 g) were heated for $70 \mathrm{~min}$ at $77 \mathrm{C}$ in one-fourth strength Ringers solution and separated into supernatant (soluble) and residue (insoluble) fractions following the procedures of Hill (1966). The Bergman and Loxley (1963) technique was used to determine the hydroxyproline content. Collagen content ( $\mathrm{mg} / \mathrm{g}$, freshtissue basis) was computed as the product of hydroxyproline content times 7.25 for the insoluble fraction and the hydroxyproline content times 7.52 for the soluble fraction (Cross et al., 1973).

Loin steaks $(2.5 \mathrm{~cm}$ thick) were removed after $7 \mathrm{~d}$ of cooler aging, frozen, thawed and cooked to $70 \mathrm{C}$ on Farberware Open Hearth ${ }^{\circledR}$ broilers. Six cores $(1.3 \mathrm{~cm}$ diameter $)$ were removed from each steak parallel to fiber direction after steaks had cooled to $4 \mathrm{C}$. These cores were sheared once with a Warner-Bratzler shear device attached to an Instron Universal Testing Machine. Peak load was recorded.

Loin steaks handled and cooked in a similar fashion were served to a 10-member, trained and tested (AMSA, 1978; Cross et al., 1978) descriptive attribute panel for evaluation of ease of fragmentation, amount of connective tissue, and overall tenderness using 8-point rating scales ( $1=$ extremely difficult, abundant, or extremely tough; 8 = extremely easy, none, or extremely tender, respectively).

Data were statistically analayzed by analysis of variance with a model containing replication, time-on-feed interval, dietary energy level and the time-on-feed $x$ energy level interaction. Means were separated by Duncan's new, multiple-range test (Steel and Torrie, 1980). The Hartley test (Steel and Torrie, 1980) was used to assess homogeneity of variance and maximum $R^{2}$ regression equations were generated using the Statistical Analysis System (Barr et al., 1979).

\section{Results}

Table 1 presents means and standard errors for live animal and carcass traits of young bulls fed varying energy levels for 30 or $60 \mathrm{~d}$. The cattle did not differ $(P>.05)$ in initial weight. After 30 or $60 \mathrm{~d}$ on feed, cattle on the highenergy feeding regimen had significantly heavier slaughter weights than those on the sub-maintenance feeding regimen. However, differences in slaughter weight did not occur for bulls on the sub-maintenance vs maintenance-energy regimen for either 30 or $60 \mathrm{~d}$. Average daily gain 
TABLE 1. MEANS AND STANDARD ERRORS FOR LIVE ANIMAL AND CARCASS TRAITS

\begin{tabular}{|c|c|c|c|c|c|c|}
\hline \multirow[b]{3}{*}{ Trait } & \multicolumn{6}{|c|}{ Feeding regimen } \\
\hline & \multicolumn{2}{|c|}{$\begin{array}{c}\text { Sub-maintenance } \\
\text { energy }\end{array}$} & \multicolumn{2}{|c|}{ Maintenance energy } & \multicolumn{2}{|c|}{ High energy } \\
\hline & $30 \mathrm{~d}$ & $60 \mathrm{~d}$ & $30 \mathrm{~d}$ & $60 \mathrm{~d}$ & $30 \mathrm{~d}$ & $60 \mathrm{~d}$ \\
\hline $\mathbf{n}$ & 8 & 8 & 8 & 8 & 8 & 8 \\
\hline Initial wt, kg & $\begin{array}{l}374.4 \\
(9.0)^{\mathrm{a}}\end{array}$ & $\begin{array}{l}374.3 \\
(10.1)\end{array}$ & $\begin{array}{r}375.9 \\
(9.6)\end{array}$ & $\begin{array}{r}372.5 \\
(8.7)\end{array}$ & $\begin{array}{r}369.9 \\
(9.2)\end{array}$ & $\begin{array}{r}381.5 \\
(9.9)\end{array}$ \\
\hline Slaughter wt, kg & $\begin{array}{c}357.8^{\mathrm{c}} \\
(10.1)\end{array}$ & $\begin{array}{l}367.5^{\mathrm{f}} \\
(12.0)\end{array}$ & $\begin{array}{c}378.4 \mathrm{bc} \\
(8.1)\end{array}$ & $\begin{array}{r}383.8^{f} \\
(7.9)\end{array}$ & $\begin{array}{l}398.6^{\mathrm{bg}} \\
(10.6)\end{array}$ & $\begin{array}{l}463.2^{\mathrm{eg}} \\
(12.0)\end{array}$ \\
\hline Avg daily gain, $\mathrm{kg}$ & $\begin{array}{l}-.55 \mathrm{dg} \\
(.23)\end{array}$ & $\begin{array}{l}-.11 \mathrm{fg} \\
(.06)\end{array}$ & $\begin{array}{r}.08^{\mathrm{c}} \\
(.11)\end{array}$ & $\begin{array}{r}.19^{f} \\
(.05)\end{array}$ & $\begin{array}{r}.96^{\mathrm{b}} \\
(.23)\end{array}$ & $\begin{array}{l}1.36^{\mathrm{e}} \\
(.06)\end{array}$ \\
\hline Carcass wt, $\mathrm{kg}$ & 241.6 & $251.0^{\mathrm{f}}$ & 251.9 & $252.9^{f}$ & $266.2 \mathrm{~g}$ & $302.1 \mathrm{eg}$ \\
\hline Quality grade & $\begin{array}{l}\mathrm{St}^{50 \mathrm{bc}} \\
(11)\end{array}$ & $\begin{array}{l}\mathrm{St}^{\mathrm{k3}} \mathrm{f} \\
(15)\end{array}$ & $\begin{array}{c}(5.6) \\
\mathrm{St}^{32} \mathrm{cg} \\
(8)\end{array}$ & $\begin{array}{l}\mathrm{St}^{71} \mathrm{fg} \\
(10)\end{array}$ & $\begin{array}{c}\mathrm{St}^{74} \mathrm{bg} \\
(14)\end{array}$ & $\begin{array}{l}\mathrm{Gd}^{45} \mathrm{eg} \\
(14)\end{array}$ \\
\hline Yield grade & $\begin{array}{l}1.19 g \\
(.06)\end{array}$ & $\begin{array}{l}1.93^{\mathrm{eg}} \\
(.16)\end{array}$ & $\begin{array}{l}1.39 \\
(.16)\end{array}$ & $\begin{array}{l}1.45^{f} \\
(.11)\end{array}$ & $\begin{array}{l}1.46 \\
(.16)\end{array}$ & $\begin{array}{l}1.76^{\mathrm{ef}} \\
(.15)\end{array}$ \\
\hline
\end{tabular}

was different for each of the feeding regimens at $30 \mathrm{~d}$. After $60 \mathrm{~d}$, however, no difference was observed between the sub-maintenance and maintenance-energy fed groups. Pen feeding to target weights may have allowed sufficient variation in feed intake within a pen (treatment) to occur and mask treatment differences. In general, bulls on the high-energy feeding regimen had higher quality and yield grades than others in the study.

The effects of feeding time and regimen on selected traits of proteolytic enzymes are presented in table 2 . In most cases, a significant difference in variance between 30 and $60 \mathrm{~d}$ of feeding was revealed by the Hartley test (Steel and Torrie, 1980). A thorough review of the procedures and data did not reveal a non-biological source of this variance. Gerrard et al. (1985) and Gray et al. (1985) reported that serum testosterone levels peak and then decrease in young bulls between 11 and 13 mo of age. Because testosterone influences rate of tissue growth and the bulls in this study were about 13 mo of age at the start of the experiment, it is possible that proteolytic-enzyme activities also are altered by hormone profiles. It is also possible that, having passed the point of testosterone peak levels, the bulls were beyond the age where the response to feeding would parallel that for steers. Although it is uncertain whether either situation exists in this study, it was decided to confine the analyses within feeding interval rather than to compensate statistically for lack of homogeneity of variance.

Feeding regimen had no effect $(\mathrm{P}>.05)$ on enzyme activities for cathepsins $B$ and $H$, and had only one significant effect on $\beta$-glucuronidase, a common lysosomal marker (table 2). This suggests that there was sufficient variation between animals to mask treatment differences.

Plasma-hydroxyproline and muscle-collagen levels in young bulls fed various energy levels for 30 or $60 \mathrm{~d}$ are displayed in table 3 . In all cases, total serum hydroxyproline decreased between 30 and $60 \mathrm{~d}$ on feed. Non-proteinbound hydroxyproline in the serum was also reduced between 30 and $60 \mathrm{~d}$ for cattle on the sub-maintenance or maintenance-energy, but not the high-energy feeding regirnen. These data suggest that a reduction in collagen turnover or degradation between 30 and $60 \mathrm{~d}$ was beginning to occur. No differences in muscle-collagen amount or solubility were detected, regardless of time-on-feed interval or regimen. It appears that the apparent reduction in collagen turnover was not sufficiently prolonged for these differ- 
TABLE 2. TOTAL AND SPECIFIC ACTIVITIES OF LONGISSIMUS MUSCLE CATHEPSIN B, CATHEPSIN H AND $\beta$-GLUCURONIDASE

\begin{tabular}{|c|c|c|c|c|c|c|}
\hline \multirow[b]{3}{*}{ Enzyme trait } & \multicolumn{6}{|c|}{ Feeding interval } \\
\hline & \multicolumn{3}{|c|}{$30 \mathrm{~d}$} & \multicolumn{3}{|c|}{$60 \mathrm{~d}$} \\
\hline & Sub-maintenance energy & Maintenance energy & High energy & Sub-maintenance energy & Maintenance energy & High energy \\
\hline \multicolumn{7}{|l|}{ Cathepsin $\mathrm{B}^{\mathrm{a}}$} \\
\hline Unbound specific activity & $\begin{array}{l}17.25 \\
(1.95)^{\mathrm{c}}\end{array}$ & $\begin{array}{l}20.96 \\
(1.95)\end{array}$ & $\begin{array}{l}18.49 \\
(2.80)\end{array}$ & $\begin{array}{l}34.90 \\
(3.35)\end{array}$ & $\begin{array}{l}35.86 \\
(3.66)\end{array}$ & $\begin{array}{l}34.16 \\
(4.81)\end{array}$ \\
\hline Bound specific activity & $\begin{array}{l}10.96 \\
(2.51)\end{array}$ & $\begin{array}{c}16.36 \\
(2.93)\end{array}$ & $\begin{array}{l}16.12 \\
(4.25)\end{array}$ & $\begin{array}{l}20.43 \\
(1.93)\end{array}$ & $\begin{array}{l}20.51 \\
(3.94)\end{array}$ & $\begin{array}{l}20.79 \\
(1.55)\end{array}$ \\
\hline Unbound total activity & $\begin{array}{c}141.86 \\
(14.92)\end{array}$ & $\begin{array}{c}179.80 \\
(23.32)\end{array}$ & $\begin{array}{c}165.37 \\
(28.81)\end{array}$ & $\begin{array}{l}318.98 \\
(33.01)\end{array}$ & $\begin{array}{l}339.57 \\
(47.25)\end{array}$ & $\begin{array}{l}317.89 \\
(46.17)\end{array}$ \\
\hline Bound total activity & $\begin{array}{l}30.73 \\
(6.95)\end{array}$ & $\begin{array}{c}46.74 \\
(7.49)\end{array}$ & $\begin{array}{c}51.63 \\
(17.58)\end{array}$ & $\begin{array}{c}62.62 \\
(6.59)\end{array}$ & $\begin{array}{c}62.37 \\
(12.00)\end{array}$ & $\begin{array}{l}64.09 \\
(5.98)\end{array}$ \\
\hline \multicolumn{7}{|l|}{ Cathepsin $\mathrm{H}^{\mathrm{a}}$} \\
\hline Unbound specific activity & $\begin{array}{c}158.90 \\
(28.22)\end{array}$ & $\begin{array}{c}156.56 \\
(33,25)\end{array}$ & $\begin{array}{c}161.61 \\
(29.94)\end{array}$ & $\begin{array}{l}94.49 \\
(7.57)\end{array}$ & $\begin{array}{c}99.76 \\
(8.97)\end{array}$ & $\begin{array}{c}115.28 \\
(11.76)\end{array}$ \\
\hline Bound specific activity & $\begin{array}{l}1.09 \\
(.47)\end{array}$ & $\begin{array}{l}1.27 \\
(.48)\end{array}$ & $\begin{array}{c}2.61 \\
(2.41)\end{array}$ & $\begin{array}{l}0.30 \\
(.17)\end{array}$ & $\begin{array}{l}0.69 \\
(.33)\end{array}$ & $\begin{array}{l}0.98 \\
(.25)\end{array}$ \\
\hline Unbound total activity & $\begin{array}{c}1,386.39 \\
(348.32)\end{array}$ & $\begin{array}{c}1,401.37 \\
(395.21)\end{array}$ & $\begin{array}{c}1,486.08 \\
(357.83)\end{array}$ & $\begin{array}{l}870.85 \\
(94.51)\end{array}$ & $\begin{array}{c}942.90 \\
(114.86)\end{array}$ & $\begin{array}{r}1,060.03 \\
(101.05)\end{array}$ \\
\hline Bound total activity & $\begin{array}{c}3.76 \\
(1.98)\end{array}$ & $\begin{array}{c}4.63 \\
(2.25)\end{array}$ & $\begin{array}{c}8.13 \\
(2.41)\end{array}$ & $\begin{array}{c}0.92 \\
(.49)\end{array}$ & $\begin{array}{c}2.33 \\
(1.20)\end{array}$ & $\begin{array}{l}3.18 \\
(.84)\end{array}$ \\
\hline \multicolumn{7}{|l|}{$\beta$-glucuronidase ${ }^{b}$} \\
\hline Unbound specific activity & $\begin{array}{c}10.90 \\
(2,51)\end{array}$ & $\begin{array}{l}12.61 \\
(2.59)\end{array}$ & $\begin{array}{l}13.16 \\
(2.21)\end{array}$ & $\begin{array}{c}7.84 \\
(1.46)\end{array}$ & $\begin{array}{c}8.08 \\
(1.67)\end{array}$ & $\begin{array}{c}9.13 \\
(1.18)\end{array}$ \\
\hline Bound specific activity & $\begin{array}{c}4.57 \\
(1.58)\end{array}$ & $\begin{array}{c}6.27 \\
(1.45)\end{array}$ & $\begin{array}{c}7.97 \\
(1.69)\end{array}$ & $\begin{array}{l}4.47 \text { de } \\
(1.31)\end{array}$ & $\begin{array}{l}3.53^{\mathrm{e}} \\
(.60)\end{array}$ & $\begin{array}{l}7.18 \mathrm{~d} \\
(.73)\end{array}$ \\
\hline Unbound total activity & $\begin{array}{c}94.77 \\
(26.72)\end{array}$ & $\begin{array}{c}109.79 \\
(28.67)\end{array}$ & $\begin{array}{l}119.52 \\
(26.05)\end{array}$ & $\begin{array}{c}71.04 \\
(13.33)\end{array}$ & $\begin{array}{c}78.34 \\
(19.29)\end{array}$ & $\begin{array}{c}86.02 \\
(13.33)\end{array}$ \\
\hline Bound total activity & $\begin{array}{l}16.47 \\
(8.00)\end{array}$ & $\begin{array}{l}21.41 \\
(7.85)\end{array}$ & $\begin{array}{c}26.86 \\
(10.08)\end{array}$ & $\begin{array}{l}12.97 \\
(3,62)\end{array}$ & $\begin{array}{l}10.73 \\
(1.81)\end{array}$ & $\begin{array}{l}22.30 \\
(2.80)\end{array}$ \\
\hline
\end{tabular}

${ }^{a}$ Specific activity presented as $\mu$ units: pmol of product produced per min per $\mathrm{mg}$ of protein. Total activity was defined as specific activity $X$ mg protein in the extract from $10 \mathrm{~g}$ of muscle.

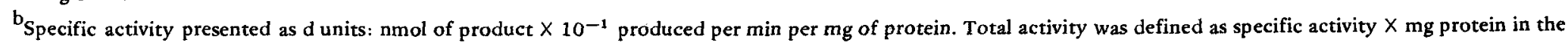
extract from $10 \mathrm{~g}$ of muscle.

${ }^{c}$ Parenthetical values are standard errors.

d,e Means in the same row within time-on-feed interval without a common superscript letter differ $(P<.05)$. 
TABLE 3. PLASMA-HYDROXYPROLINE AND LONGISSIMUS-MUSCLE COLLAGEN CHARACTERISTICS OF YOUNG BULLS

\begin{tabular}{|c|c|c|c|c|c|c|}
\hline \multirow[b]{3}{*}{ Trait } & \multicolumn{6}{|c|}{ Feeding regimen } \\
\hline & \multicolumn{2}{|c|}{ Sub-rnaintenance energy } & \multicolumn{2}{|c|}{ Maintenance energy } & \multicolumn{2}{|c|}{ High energy } \\
\hline & $30 \mathrm{~d}$ & $60 \mathrm{~d}$ & $30 \mathrm{~d}$ & $60 \mathrm{~d}$ & $30 \mathrm{~d}$ & $60 \mathrm{~d}$ \\
\hline \multicolumn{7}{|l|}{ Serum } \\
\hline \multirow[t]{2}{*}{ Total hydroxyproline, $\mathrm{g} / \mathrm{ml}$} & $9.15^{\mathrm{a}}$ & $7.79^{a}$ & $9.21^{\mathrm{a}}$ & $7.90^{\mathrm{a}}$ & $8.90^{\mathrm{a}}$ & 7.88 \\
\hline & $(.53)^{b}$ & (1.07) & $(.39)$ & $(.33)$ & $(.47)$ & $(.63)$ \\
\hline \multirow{2}{*}{ Non-protein hydroxyproline, $\mathrm{g} / \mathrm{ml}$} & $6.13^{\mathrm{a}}$ & $4.28^{\mathrm{a}}$ & $5.65^{\mathrm{a}}$ & $4.24^{a}$ & 5.16 & 5.28 \\
\hline & $(.34)$ & $(.41)$ & $(.21)$ & $(.14)$ & $(.25)$ & $(.65)$ \\
\hline \multirow[t]{2}{*}{ Non-protein hydroxyproline, $\%$} & 68.43 & 57.64 & 61.80 & 53.94 & 58.47 & 67.22 \\
\hline & $(5.20)$ & $(5.20)$ & $(2.40)$ & $(2.27)$ & $(2.47)$ & $(5.65)$ \\
\hline \multicolumn{7}{|l|}{ Muscle } \\
\hline \multirow[t]{2}{*}{ Total collagen, $\mathrm{mg} / \mathrm{g}$} & 4.79 & 4.62 & 4.47 & 4.65 & 4.54 & 4.43 \\
\hline & $(.44)$ & $(.35)$ & $(.38)$ & $(.24)$ & $(.35)$ & $(.15)$ \\
\hline \multirow[t]{2}{*}{ Soluble collagen, $\mathrm{mg} / \mathrm{g}$} & .73 & .71 & .65 & .75 & .70 & .76 \\
\hline & $(.07)$ & $(.11)$ & $(.09)$ & $(.07)$ & $(.04)$ & $(.08)$ \\
\hline \multirow[t]{2}{*}{ Soluble collagen, $\%$} & 16.27 & 15.31 & 14.80 & 16.24 & 15.86 & 17.07 \\
\hline & $(2,12)$ & (1.99) & $(1.77)$ & $(1.40)$ & $(1.35)$ & $(1.44)$ \\
\hline
\end{tabular}

${ }^{\mathrm{a}}$ Means in the same row within feeding regimen differ $(\mathrm{P}<.05)$.

${ }^{b}$ Parenthetical values are standard errors. 
ences to manifest themselves within the muscle. Wu et al. (1981) found that collagen turnover was accelerated during the rapid growth phase of cattle. Conversely, these data indicate that a drop in growth rate is associated with a decline in collagen turnover.

Feeding interval ( 30 vs $60 \mathrm{~d}$ ) or regimen did not alter tenderness characteristics of longissimus muscle (table 4). While the population did vary in tenderness traits (as indicated by the standard errors), this variance was generally uniformly distributed across the treatments.

Because enzyme, serum hydroxyproline, muscle collagen and tenderness characteristics of individual animals were known, the opportunity existed to evaluate interrelationships between these measurements. This was accomplished using regression analysis within each of the feeding intervals.

The best, five-variable regression equations selected from a pool of enzyme traits as independent variables for the dependent variables of serum-hydroxyproline and muscle-collagen levels are in table 5. In all but one case, these equations were significant and accounted for over $50 \%$ of the variation in the dependent variables. The frequency with which particular enzyme traits appear in the regression equations does not seem to follow a particular pattern; all enzymes are represented in nearly every equation. This strongly suggests that changes in amount of serum hydroxyproline and amount or solubility of muscle collagen are related to proteolytic-enzyme activities.

Regression analyses for taste-panel ratings and shear-force values are shown in table 6 . For all cattle fed $30 \mathrm{~d}$, selected enzyme measurements accounted for 46 to $60 \%$ of the variation in sensory traits. After $60 \mathrm{~d}$ on feed, however, the regression equations were lower for tastepanel ratings ( $P>.05)$. The explained variation in shear forces remained significant, but unchanged. It is unclear if the apparent decline in the relationship was a result of modified biological activity with the muscle.

\section{Discussion}

Changes observed in serum hydroxyproline relative to muscle collagen suggest that the feeding interval in this study should have been extended. This could have been the reason that no enzyme differences were detected between feeding regimens, despite some large differences in rate of gain. The study was designed to allow sufficient time on each feeding regimen

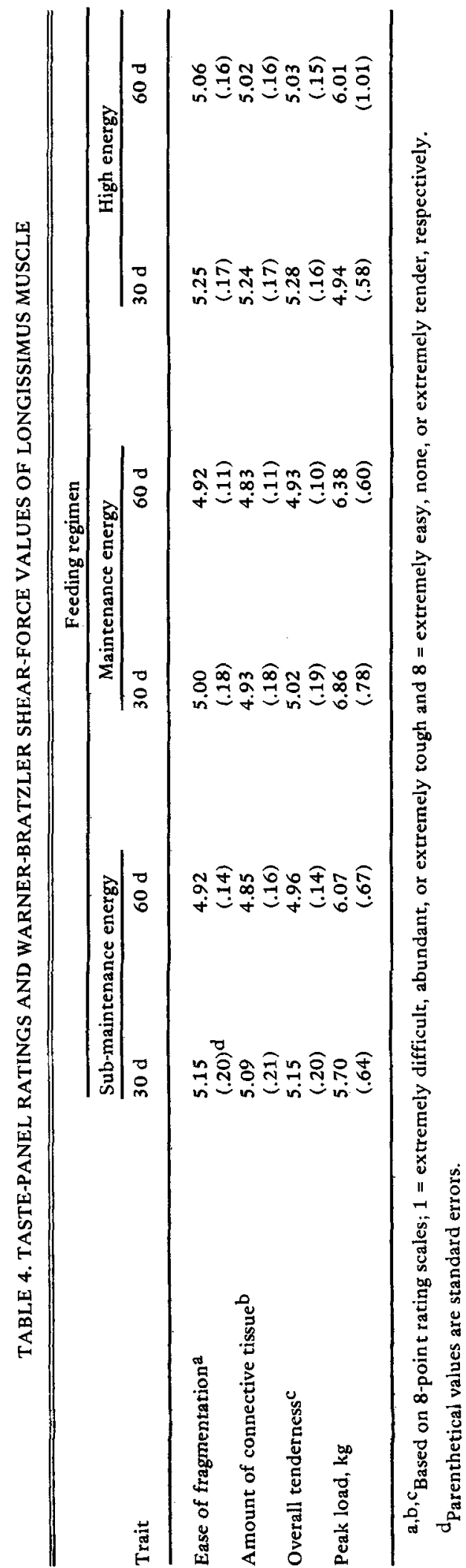


TABLE 5. BEST FIVE-VARIABLE REGRESSION EQUATION ANALYSES FOR ENZYME MEASUREMENTS VERSUS SERUM HYDROXYPROLINE AND MUSCLE COLLAGEN

\begin{tabular}{|c|c|c|c|c|c|}
\hline Dependent variable & Days on feed & $\begin{array}{c}\text { Variables in regression } \\
\text { equation }^{\mathrm{a}}\end{array}$ & $C D^{b}$ & Probability of $F$ & SEE ${ }^{\mathrm{C}}$ \\
\hline \multicolumn{6}{|l|}{ Serum } \\
\hline \multirow[t]{2}{*}{ Total hydroxyproline } & 30 & $3,11,13,19,20$ & 51.60 & .015 & .996 \\
\hline & 60 & $3,6,12,13,21$ & 50.54 & .032 & 1.700 \\
\hline \multirow[t]{2}{*}{ Non-protein hydroxyproline } & 30 & $3,4,7,10,19$ & 59.93 & .003 & .603 \\
\hline & 60 & $6,10,12,14,21$ & 65.36 & .002 & .915 \\
\hline \multirow[t]{2}{*}{ Non-protein hydroxyproline, \% } & 30 & $4,8,10,13,19$ & 72.96 & .001 & 6.239 \\
\hline & 60 & $5,11,14,15,21$ & 64.59 & .003 & 9.570 \\
\hline \multicolumn{6}{|l|}{ Muscle } \\
\hline \multirow[t]{2}{*}{ Total collagen } & 30 & $2,3,5,17,19$ & 62.31 & .003 & .733 \\
\hline & 60 & $1,3,6,16,19$ & 59.45 & .005 & .514 \\
\hline \multirow[t]{2}{*}{ Soluble collagen } & 30 & $2,6,7,13,17$ & 54.75 & .012 & .148 \\
\hline & 60 & $1,2,4,6,9$ & 51.58 & .021 & .183 \\
\hline \multirow[t]{2}{*}{ Soluble collagen, $\%$} & 30 & $4,8,15,16,21$ & 66.00 & .001 & .320 \\
\hline & 60 & $2,4,6,10,18$ & 36.95 & .132 & .399 \\
\hline
\end{tabular}

${ }^{a}$ Variables used in regression equations:

$1,2,3=$ unbound specific activity, $\beta$-glucuronidase, cathepsin $H$ and cathepsin $B$, respectively.

$4,5,6=$ bound specific activity, $\beta$-glucuronidase, cathepsin $H$ and cathepsin $B$, respectively.

$7,8,9=$ unbound total activity, $\beta$-glucuronidase, cathepsin $H$ and cathepsin $B$, respectively.

$10,11,12=$ bound total activity, $\beta$-glucuronidase, cathepsin $H$ and cathepsin $B$, respectively.

$13,14,15=\%$ unbound total activity, $\beta$-glucuronidase, cathepsin $H$ and cathepsin $B$, respectively.

$16,17=\%$ bound total activity, $\beta$-glucuronidase and cathepsin $H$, respectively.

$18,19=$ overall total activity, $\beta$-glucuronidase and cathepsin $B$, respectively.

$20,21=$ protein concentration in solutions for unbound and bound enzymes, respectively.

${ }^{\mathrm{b}} \mathrm{CD}=$ coefficient of determination $\left(\mathrm{R}^{2} \times 100\right)$.

${ }^{\mathrm{c}} \mathrm{SEE}=$ standard error of the estimate. 
TABLE 6. BEST FIVE-VARIABLE REGRESSION EQUATION ANALYSES FOR ENZYME MEASUREMENTS VERSUS TASTE-PANEL RATINGS AND WARNER-BRATZLER SHEAR-FORCE VALUES

\begin{tabular}{|c|c|c|c|c|c|}
\hline Dependent variable & Days on feed & $\begin{array}{c}\text { Variables in the regression } \\
\text { equation }^{\mathrm{a}}\end{array}$ & $C D^{b}$ & Probability of $F$ & SEEC \\
\hline \multirow[t]{2}{*}{ Ease of fragmentation } & 30 & $9,10,11,16,18$ & 60.94 & .003 & .359 \\
\hline & 60 & $1,4,6,7,15$ & 35.16 & .135 & .347 \\
\hline \multirow[t]{2}{*}{ Amount of connective tissue } & 30 & $3,11,14,18,19$ & 57.51 & .005 & .388 \\
\hline & 60 & $1,4,6,7,15$ & 37.34 & .106 & .360 \\
\hline \multirow[t]{2}{*}{ Overall tenderness } & 30 & $9,10,11,16,18$ & 59.12 & .004 & .368 \\
\hline & 60 & $1,4,6,7,12$ & 37.27 & .107 & .326 \\
\hline \multirow{2}{*}{ Peak load, kg } & 30 & $2,3,6,10,13$ & 46.12 & .035 & 1.628 \\
\hline & 60 & $3,5,6,8,17$ & 45.46 & .038 & 1.769 \\
\hline
\end{tabular}

${ }^{\mathrm{a}}$ Variables used in regression equations.

$1,2=$ unbound specific activity, $\beta$-glucuronidase and cathepsin $H$, respectively.

$3,4,5=$ bound specific activity, $\beta$-glucuronidase, cathepsin $H$ and cathepsin $B$, respectively.

$6,7,8=$ unbound total activity, $\beta$-glucuronidase, cathepsin $H$ and cathepsin $B$, respectively.

$9,10=$ bound total activity, $\beta$-glucuronidase and cathepsin $H$, respectively .

$11,12=\%$ unbound total activity, $\beta$-glucuronidase and cathepsin $B$, respectively

$13,14,15=\%$ bound total activity, $\beta$-glucuronidase, cathepsin $H$ and cathepsin $B$, respectively.

$16,17,18=$ overall total activity, $\beta$-glucuronidase, cathepsin $H$ and cathepsin $B$, respectively.

$19=$ protein concentration in solutions for unbound enzymes.

${ }^{b} \mathrm{CD}=$ coefficient of determination $\left(\mathrm{R}^{2} \times 100\right)$.

${ }^{c} \mathrm{SEE}=$ standard error of the estimate. 
for long-term changes in induction of enzyme synthesis to occur. No evidence exists that this was accomplished. Those data within the literature that demonstrate differences in rate of gain and meat tenderness or collagen turnover (Aberle et al., 1981; Wu et al., 1981; Hall and Hunt, 1982) are from steers held under experimental treatment for extended periods of time ( $\geqslant 98 \mathrm{~d}$ in all but one instance).

Although no treatment effects were noted for tenderness measures, there was a range in Warner-Bratzler shear-force values form 2.91 to $11.20 \mathrm{~kg}(\mathrm{C} . \mathrm{V} .=33.85)$ for the entire population. The coefficients of variation for taste-panel ratings were lower $(8.96,9.48$ and 8.83 for ease of fragmentation, amount of connective tissue and overall tenderness, respectively) than the coefficient of variation for shear-force values. With this degree of variance within the population, it was deemed appropriate to investigate the relationships between enzyme activities and palatability measures.

The relatively high (approximately 50\%) coefficients of determination between enzyme activities and serum hydroxyproline, muscle collagen or palatability indicate a strong relationship between proteolytic enzymes and these measures. It must be acknowledged, however, that these data do not conclusively demonstrate that the relationship is one of cause and effect. For example, the synthetic, fluorimetric substrate used to quantitate cathepsin B also can be degraded by cathepsin L. In muscle there are much larger amounts of $B$ than $L$; thus we tend to attribute all of the activity to cathepsin B (Kirschke et al., 1982). Similarly, there has been much discussion about the role of calcium-activated factor (CAF), a neutral protease, in degradation of muscle proteins (Koohmaraie et al., 1986; Lowell et al., 1986). No studies have been reported that compare concentration or activity of CAF and cathepsins. The possibility exists that changes in catheptic-enzyme traits reflect changes in neutral proteases. If this is true, then the apparent relationship between cathepsins and palatability could be due to the indirect relationship between CAF and the cathepsins. Further research is needed to address this aspect of the study.

\section{Conclusions}

Results of this study suggest that low- or maintenance-energy diets can reduce the rates of connective-tissue degradation. Although feed- ing regimen did not alter meat palatability, a relationship does exist between enzyme measurements and meat tenderness. Further research is needed to determine if hormone profiles alter enzyme activities and to assess the relative importance of various endogenous enzymes in tenderization of meat.

\section{Literature Cited}

Aberle, E. D., E. S. Reeves, M. D. Judge, R. E. Hunsley and T. W. Perry. 1981. Palatability and muscle characteristics of cattle with controlled weight gain: Time on a high energy diet. J. Anim. Sci. 52:757.

AMSA. 1978. Guidelines for cookery and sensory evaluation of meat. Amer. Meat Sci. Assoc. and Natl. Live Stock and Meat Board, Chicago, IL.

Bannister, D. W. and A. B. Burns. 1970. Adaptation of the Bergman and Loxley technique for hydroxyproline determination to the autoanalyzer and its use in determining plasma hydroxyproline in the domestic fowl. Analyst $95: 596$.

Barr, A. J., J. H. Goodnight, J. P. Sall, W. H. Blair and D. M. Chilko. 1979. A User's Guide to SAS 79. SAS Institute, Raleigh, NC.

Barrett, A. J. 1980. Fluorimetric assays for cathepsin $B$ and cathepsin $H$ with methylcoumarylamide substrates. Biochem. J. 187:909.

Bergman, I. and R. Loxley. 1963. Two improved and simplified methods for the spectrophotometric determination of hydroxyproline. Anal. Chem. $35: 1961$.

Bird, J.W.C., A. M. Spanier and W. N. Schwartz. 1978. Cathespins $B$ and D: Proteolytic activity and ultrastructural localization in skeletal muscle. In: H. L. Segal and D. J. Doyle (Ed.). Protein Turnover and Lysosome Function. pp 589-604. Academic Press, New York.

Cross, H. R., Z. L. Carpenter and G. C. Smith. 1973. Effects of intramuscular collagen and elastin upon bovine muscle tenderness. J. Food Sci. 38:998.

Cross, H. R., R. Moen and M. Stanfield, 1978. Training and testing of judges for sensory analysis of meat quality. Food Technol. 32(7):48.

Crouse, J. D., C. R. Calkins and S. C. Seideman. 1986. The effects of rate of change in body weight on tissue development and meat quality of youthful bulls. J. Anim. Sci. $63: 1824$.

Fishell, V. K., E. D. Aberle, M. D. Judge and T. W. Perry. 1985. Palatability and muscle properties of beef as influenced by pre-slaughter growth rate. J. Anim. Sci. 61:151.

Gerrard, D. E., E. D. Aberle, R. P. Lemenager and M. $D$. Judge. 1985. Intramuscular collagen characteristics, testosterone secretion and meat tenderness in growing bulls and steers. NCR-132. Annu. Rep. CSRS, Washington D.C.

Gray, D. G., J. A. Unruh, M. E. Dikeman and J. S. Stevenson. 1985. Endocrine aspects of zeranol implanted young bulls. J. Anim. Sci. 61 (Suppl. 1): 169 .

Hall, J. B. and M. C. Hunt. 1982. Collagen solubility of A-maturity bovine longissimus muscle as 
affected by nutritional regimen. J. Anim. Sci. $55: 321$

Hill, F. 1966. The solubility of intramuscular collagen in meat animals in various ages. J. Food Sci. $31: 161$.

Kirschke, H., A. A. Kembhavi, P. Bohley and A. J. Barrett. 1982. Action of rat liver cathepsin $L$ on collagen and other substrates. Biochem. J. 201:367.

Koohmaraie, M., J. E. Schollmeyer and T. R. Dutson. 1986. Effect of low-calcium-requiring calcium activated factor of myofibrils under varying $\mathrm{pH}$ and temperature conditions. J. Food Sci. 51:28.

Lowell, B., N. B. Ruderman and M. N. Goodman. 1986. Evidence that lysosomes are not involved in the degradation of myofibrillar proteins in rat skeletal muscle. Biochem. J. 234:237.

Miller, R, K., J. D. Tatum, H. R. Cross, R. A. Bowling and R. P. Clayton. 1983. Effects of carcass maturity on collagen solubility and palatability of beef from grain-finished steers. J. Food Sci. $48: 484$.

Millward, D. J., P. J. Garlick, R.J.C. Stewart, D. O. Nnanyelugo and J. C. Waterflow. 1975. Skeletal-muscle growth and protein turnover. Biochem. J. 150:235.

Millward, D. J. and J. C. Waterflow. 1978. Effect of nutrition on protein turnover in skeletal muscle. Fed. Prod. 37:2283.

Moeller, P. W., P. A. Fields, T. R. Dutson, W. A. Landmann and Z. L. Carpenter. 1976. Effect of high temperature conditioning on subcellular distribution and levels of lysosomal enzymes. J. Food Sci. 41:216.

Steel, R.G.D. and J. H. Torrie. 1980. Principles and Procedures of Statistics (2nd Ed.). McGraw-Hill Book Co., New York.

Wu, J. J., C. L. Kastner, M. C. Hunt, D. H. Kropf and D. M. Allen. 1981. Nutritional effects on beef collagen and palatability. J. Anim. Sci. 53:1256. 